\title{
Content of Selected Macro- and Microelements in the Liver of Free-Living Wild Boars (Sus scrofa L.) from Agricultural Areas and Health Risks Associated with Consumption of Liver
}

\author{
Anna Kasprzyk ${ }^{1, *} \mathbb{1}$, Janusz Kilar ${ }^{2,3}$, Stanisław Chwil ${ }^{4}$ and Michał Rudaś ${ }^{5}$ \\ 1 Department of Pig Breeding and Biotechnology, Institute of Animal Breeding and Biodiversity Conservation, \\ University of Life Sciences in Lublin, 13 Akademicka, 20-950 Lublin, Poland \\ 2 Institute of Agricultural and Forest Economy, Jan Grodek State University in Sanok, 21 Mickiewicza, \\ 38-500 Sanok, Poland; janusz.kilar@wp.pl \\ 3 Podkarpacki Agricultural Advisory Center in Boguchwala, 9 Suszyckich, 36-040 Boguchwala, Poland \\ 4 Department of Chemistry, Faculty of Food Science and Biotechnology, University of Life Sciences in Lublin, \\ 15 Akademicka, 20-950 Lublin, Poland; stanislaw.chwil@up.lublin.pl \\ 5 Central Laboratory of Research, University of Life Sciences in Lublin, 30 D Głęboka, 20-612 Lublin, Poland; \\ michal.rudas@up.lublin.pl \\ * Correspondence: anna.kasprzyk@up.lublin.pl
}

Received: 7 August 2020; Accepted: 19 August 2020; Published: 27 August 2020

check for updates

Simple Summary: Liver is a traditional dish and a basic ingredient of traditional dishes consumed in many countries worldwide. The analysis of trace elements and macro- and microelements in the liver of wild boars is important due to the insufficient amount of available scientific information in this field. The material comprised liver samples taken from 70 wild boars (Sus scrofa L.). The animals represented the following ranges of age: Up to one year (group I), from one to three years (group II), and over three to five years (group III). It was shown that the wild boar liver is a rich source of mineral compounds. The age was found to exert an effect on the concentration of most minerals. The sex significantly determined the content of iron, calcium, and cadmium. The results obtained in our study indicate that children should avoid a frequent intake of wild boar liver. In turn, this type of liver can be a valuable source of such elements as $\mathrm{Fe}, \mathrm{Zn}$, and $\mathrm{Cu}$ for adults. The permissible concentration of $\mathrm{Cd}$ in the liver was exceeded in five samples. We suggest that regular control of the content of trace elements in wild boar liver is extremely important and advisable for assessment of the level of consumer exposure. The toxic metal content can be determined to assess the degree of environmental pollution and for biomonitoring of contamination. The information included in this article may be useful for environment protection agencies and policy makers that design strategies for environmental protection and human health and safety regulations.

Abstract: The aim of the study was to determine the levels of selected toxic and non-toxic elements in the liver of free-living wild boars from agricultural areas and to assess health risks associated with liver consumption. Samples were collected from 70 wild boars. The animals were divided into three age groups (group I up to one year, group II from one to three years, group III over three to five years). It was shown that wild boar liver is a rich source of mineral compounds $(\mathrm{K}, \mathrm{Fe}, \mathrm{Mg}, \mathrm{Ca}$, $\mathrm{Zn}$, and $\mathrm{Cu}$ ). The age was found to exert an effect on the concentration of most minerals. The sex significantly determined the content of $\mathrm{Fe}, \mathrm{Ca}$, and $\mathrm{Cd}$. The maximum allowable level of $\mathrm{Cd}$ in the liver was exceeded in two and three samples from groups I and III, respectively. Therefore, regular monitoring of the content of this element in tissues of game animals is extremely important and advisable to assess the consumer exposure to this metal. From the point of view of human health, the estimation of the non-carcinogenic risk indicated that the intake of individual trace elements through the consumption of the liver was safe, whereas consumption of combined trace elements 
(only in the case of the consumption of the wild boar liver twice a week) suggested a potential health risk to children.

Keywords: wild boar; toxic elements; essential elements; health risk assessment; hazard index

\section{Introduction}

A vast majority of metals contained in Earth's crust is represented by trace elements, which are indispensable for the proper function of living organisms. Their presence in the environment is a result of natural geological processes [1]. However, the increasing industrial production and agricultural activity have led to a drastic increase in environmental contamination (air, plants, soil, and water), and consequently, exposure of living organisms (plants, animals, and humans) to a variety of toxic substances, including heavy metals [2-5]. Cadmium contained in soil persists on its surface for many years. It becomes a component of humus, where it is easily absorbed by plants. The bioaccumulation and phytoavailability index is 10 in the case of cadmium and below one in the case of another equally harmful heavy metal, i.e., lead [6]. Over time, potentially toxic trace elements (PTE) can reach levels that will pose a serious threat to ecological balance [6]. Additionally, heavy metals are a serious hazard to human health. Increasing concentrations of $\mathrm{Pb}$ and $\mathrm{Cd}$ have been recorded in soil, water, and sediments from mining and smelting areas in Europe [2,3,7-9]. Their direct sources are wastewater, sewage, industrial and municipal dusts and smoke, and exhaust gases. The processes of coal burning, including the so-called low emission, contribute substantially to the emission of metals into the atmosphere. Due to their small sizes, dusts emitted in this way can be transported with air circulation over long distances and deposited not only in the immediate vicinity of emitters. As reported by Šajn et al. [9], emissions from some types of factories can contaminate the environment at distances up to $152 \mathrm{~km}$. Given the observations of PTE pollution over large areas, research methods based on biological detectors of its accumulation have become important in recent years. The use of indicator species can provide data for monitoring the quality and contamination of the biological environment $[5,10]$. Such animal species as fish, birds, and rodents have been used as bioindicators of environmental pollution. The wild boar has also been reported in the literature $[4,11,12]$ as a good or even excellent indicator of the environmental contamination with toxic elements. This species is a suitable bioindicator due to its wide geographical distribution (occurrence in many countries of the globe), nutritional habits (carnivore and herbivore), a relatively long lifespan (up to 20-30 years), and the ease of sampling facilitated by regular culling [13].

Lead and cadmium are one of the most common contaminants with a tendency towards bioaccumulation by both plants and animals and inefficient processes of natural detoxification. When absorbed by the mammalian organism, $\mathrm{Cd}$ and $\mathrm{Pb}$ accumulate mainly in the liver and kidneys $[10,14,15]$. The tendencies towards accumulation of $\mathrm{Cd}$ and $\mathrm{Pb}$ and the lack of an effective mechanism for elimination thereof pose a potentially serious threat to animal and human health [14]. In humans, cadmium is a carcinogenic and mutagenic element [16]. The presence of these metals in the human and animal environment is a serious health-related and ecological problem. The degree of heavy metal accumulation in organs depends on the amount of ingested food and water, soil contamination, airborne concentration, and biological half-life, which is 10-30 years in the case of $\mathrm{Cd}$ and $\mathrm{Pb}$ [17]. Even in trace amounts, cadmium is regarded as a toxic element due to limitation of biotransformation processes, which results in slow excretion thereof and accumulation in living organisms. Therefore, the pathological effects of cadmium to organs and tissues strongly indicate the need for controlling the amount of cadmium in foodstuffs. Hence, it is indispensable to monitor cadmium concentrations in the environment, cities, and industrial regions and in areas that are not directly related to sources of pollution [12]. Toxic metals are absorbed from the diet relatively easily. Some potentially toxic trace elements, e.g., $\mathrm{Co}, \mathrm{Cu}, \mathrm{Fe}, \mathrm{Se}$, and $\mathrm{Zn}$, are indispensable for living organisms. However, when ingested 
at higher than allowable concentrations, they may disturb the functions of enzymes and are responsible for the occurrence of many conditions, in particular diseases of the nervous and cardiovascular system or bone disorders in mammals [11,16,18].

Red meat is an important source of minerals in the human diet, as it provides highly bioavailable elements required for normal development and health [19]. Minerals contained in meat, in comparison with those present in plants, are more easily absorbed [20]. Macro- and microelements are the building material of bones, teeth, skin, and hair and are fundamental components for metabolic processes, maintenance of acid-base equilibrium, and regulation of water and electrolyte metabolism [21]. To date, no specific limits have been established in the European Union for toxic metals in game meat and offal, and the regulations regarding lead and cadmium are limited to the minimum risk levels (MRLs) listed in Reg. 629/2008 for pigs and other farmed species [22].

The concentration of elements in animal tissues can be influenced by such factors as animals' age and sex, sampling season (hunting), and nutrition [5,10,12,23,24]. A significant impact on the content of heavy metals is undoubtedly exerted by the living habitat of game animals, which is much more closely related to the environment than that of farm animals [25]. Since bioaccumulation of toxic metals originating from anthropogenic pollution is becoming a potential threat to human health [26], systematic monitoring of the presence of heavy metals is necessary not only in industrialized areas but also in agricultural regions [12]. To date, there are few studies assessing the heavy metal pollution in the liver of wild boars induced by agricultural activities. There is limited information available to consumers about the mineral content in the liver of the wild boar. The novelty of this study is the assessment of the potential consumer health risk related to consumption of livers of wild boars foraging in agricultural areas.

The aim of the study was to determine the levels of selected toxic and non-toxic elements in the liver of free-living wild boars from agricultural areas of Poland and to assess health risks associated with liver consumption.

\section{Materials and Methods}

\subsection{Feeding Grounds of the Wild Boar}

The wild boars lived in an agricultural region $\left(90,270 \mathrm{~km}^{2}\right)$ in the southeast covering the area of the following voivodeships: Lubelskie, podkarpackie, podlaskie, and mazowieckie. This is an area with $59 \%$ of arable land and $31 \%$ of forests. Plants cultivated in the fields include cereals (wheat, maize, barley, and triticale), potatoes, fodder plants, and vegetables. The forests are dominated by pine as well as birch, oak, spruce, beech, and alder. The area is a typical lowland and upland agricultural region covered predominantly by brown soils with some admixture of rendzinas and podzolic soils. The animals lived in forests, crop fields, and meadows away from heavy industry [10]. The region is characterized by a moderate continental climate. The average annual precipitation rate is $514 \mathrm{~mm}$ and the average annual air temperature is $9.5^{\circ} \mathrm{C}$. South-western winds prevail in the region.

Samples of the posterior segment of livers collected from 70 wild boars in collaboration with official local hunting authorities were the research material. No ethical committee permission was required, as the samples were collected post-mortem. The wild boars were culled by hunters as part of the hunting economy scheme and hunting limits (Journal of Laws 1995 No. 147 item 713; Bill of 13 October 1995, Hunting law as amended) in Poland in the hunting season of 2017. The wild boars originated from regular controlled culling approved by the Ministry of Environment and carried out to obtain meat for consumption.

\subsection{Sample Preparation}

Approximately $300 \mathrm{~g}$ of liver tissue were dissected from the left lobe of the liver. All samples were divided into three age groups (group I up to one year young-16 animals, group II from one to three years -28 animals, group III over three to five years old -26 animals) taking into account the animals' 
sex (females $n=32$; males $n=38$ ). The age of the wild boars was determined on the basis of external appearance (colour, height, length of fang wear). The samples were packed separately into plastic bags, transported to the laboratory, and stored at $-18^{\circ} \mathrm{C}$ until analysis.

\subsection{Elemental Analysis}

The samples were thawed at $4{ }^{\circ} \mathrm{C}$ for $24 \mathrm{~h}$. Thawed samples were ground using an analytical mill and ca. 0.5-g aliquots of the homogeneous mass were weighed on an analytical balance with an accuracy of $0.0001 \mathrm{~g}$ and placed in Teflon tubes. The aliquots were flooded with $10 \mathrm{~cm}^{3} \mathrm{HNO}_{3}$ (Suprapur-Merck). Capped tubes were transferred to the mineralizer rotor. The samples were mineralized in a CEM Mars Xpress Matthews, NC, USA microwave oven at a temperature of $210{ }^{\circ} \mathrm{C}$ and a pressure of approximately 7 atmospheres. The transparent mineralizates were quantitatively transferred to $50 \mathrm{~cm}^{3}$ volumetric flasks and diluted with demineralized water (conductivity $0.055 \mu \mathrm{S} / \mathrm{cm}$ ) to the marking. The content of mineral components $(\mathrm{K}, \mathrm{Ca}, \mathrm{Mg}, \mathrm{Fe}, \mathrm{Zn}, \mathrm{Mn}$, and $\mathrm{Cu})$ was determined using the flame atomic absorption spectrometry technique (AAS-Varian SpectrAA 280 FS). The determination was carried out based on the calibration curve using background correction with a deuterium lamp. All elements were analyzed in the air/acetylene stoichiometric flame. Spectral Schinkel buffer solution was used for some elements, e.g., $\mathrm{K}, \mathrm{Ca}$, and $\mathrm{Mg}$. To determine the concentration of $\mathrm{Cd}, \mathrm{Pb}, \mathrm{As}$, and $\mathrm{Ni}$, the solutions were analyzed on an inductively coupled plasma mass spectrometer (ICP Mass Spectrometer Varian MS-820 Belrose, Australia). The following isotopes of the analyzed elements were used: ${ }^{60} \mathrm{Ni},{ }^{75} \mathrm{As}$, ${ }^{111} \mathrm{Cd},{ }^{206} \mathrm{~Pb},{ }^{207} \mathrm{~Pb}$, and ${ }^{208} \mathrm{~Pb}$. Ultra Scientific standards with $99.999 \%$ purity and Merck Suprapure nitric $(\mathrm{V})$ and hydrochloric acids were used in the analysis. Validation parameters used in the analysis are shown in Table 1 . The quality control in the analysis was achieved by measurements of the blank sample, double sample, and certified reference material "NIST-1577c Bovine Liver". Nitrogen was determined with the Kjeldahl method on a Kjeltec 2100 Hilleroed, Denmark Foss Tecator device in accordance with the PN-A-04018 standard [27]. Phosphorus was determined colorimetrically following the methodology proposed by Fiske and Subbarowa [28] with the use of the Cecil 2011 (Cambridge, UK) apparatus. The analyses were performed in triplicate. The results were expressed in $\mathrm{mg} \cdot \mathrm{kg}^{-1}$ of meat weight. The research was conducted in the certified Central of Laboratory of Agroecology of the University of Life Sciences in Lublin.

Table 1. Results of the analysis of certified reference materials and proficiency tests.

\begin{tabular}{|c|c|c|c|c|}
\hline Element & LOQ (mg.kg $\left.{ }^{-1}\right)$ & Certified Value (mg.kg $\left.{ }^{-1}\right)$ & Analyzed Value (mg $\left.\mathrm{kg}^{-1}\right)$ & Recovery $(\%)$ \\
\hline $\mathrm{Ca}$ & 56 & 131 & 129.17 & 99 \\
\hline $\mathrm{Mg}$ & 36 & 620.42 & 651.87 & 105 \\
\hline $\mathrm{Fe}$ & 8.6 & 197.94 & 190.53 & 96 \\
\hline $\mathrm{Mn}$ & 2.2 & 10.46 & 10.27 & 97 \\
\hline $\mathrm{Cu}$ & 2.6 & 275.20 & 274.50 & 99 \\
\hline $\mathrm{Zn}$ & 0.9 & 181.10 & 102.88 & 106 \\
\hline K & 40 & 10.23 & 9.45 & 94 \\
\hline $\mathrm{Cd}$ & 0.8 & 0.097 & 0.097 & 100 \\
\hline $\mathrm{Pb}$ & 1.3 & 0.063 & 0,069 & 110 \\
\hline As & 0.9 & 0.019 & 0.019 & 97 \\
\hline $\mathrm{Ni}$ & 1.1 & 0.045 & 0.047 & 106 \\
\hline
\end{tabular}

LOQ: Limit of quantification.

2.4. Nutritional Assumptions Used for Assessment of the Dietary Intake of Elements and Potential Consumer Health Risk (HQ) and Hazard Index (HI)

The consumers were divided into three groups according to the frequency of consuming liver: Those consuming wild boar liver frequently (90 times a year), those consuming liver periodically (12 times a year), and those consuming liver occasionally (two times a year). A portion of liver was assumed to be $138.4 \mathrm{~g}$ for an adult and $111.2 \mathrm{~g}$ for a child. The potential health risk (HQ) for consumers was assessed based on the concentrations of selected elements contained in the liver. 
The risk values were calculated using the formula:

$$
\mathrm{HQ}=\mathrm{EDI} / \mathrm{RfD}
$$

where EDI is the estimated daily intake (mg/kg b.w./day) and RfD is the reference dose [29].

$$
\mathrm{EDI}=\frac{C \times E F \times E D \times L C}{B W \times T}: 1000[\mathrm{mg} / \mathrm{kg} / \text { day }]
$$

where $C$ is the element content $(\mu \mathrm{g} / \mathrm{g}), \mathrm{EF}$ is the exposure frequency (days/year), $\mathrm{ED}$ is the duration of exposure (70 years for adults, six years for children), LC is the liver consumption (g), BW is the average body weight (70 kg for adults, $20 \mathrm{~kg}$ for children), and $\mathrm{T}$ is the average exposure time (365.ED).

The hazard index (HI) was calculated as the sum of HQ values [29]. When the HQ value is less than 1, the exposed population is unlikely to experience any adverse health hazard. When the HQ exceeds 1 , there might be concerns for potential noncancerous effects.

\subsection{Statistical Analysis}

The analyses were performed using the STATISTICA 13.1 software Kraków, Poland for analysis of data. The normality was assessed using the Kolmogorov-Smirnov test, and Levene's homogeneity of variance test was applied to examine the equality of variances. To determine the effect of the age and sex (as well as their interaction) on the analyzed traits, two-way analysis of variance with Tukey's test was used at a significance level of $p<0.05$ and $p<0.01$. Basic statistical calculations were performed for each variable with determination of the mean, standard error, geometric mean (GM), and the minimum and maximum values.

\section{Results}

The content of heavy metals is presented in Table 2 . There were statistically significant differences $(p \leq 0.01)$ in the lead content in the livers between groups I and II. No statistically significant differences were observed in the content of $\mathrm{Cd}$ between the analyzed groups; however, higher values of this element were noted in the livers of the over three-year-old wild boars. Furthermore, the maximum allowable level of this metal in the liver $(0.5 \mathrm{mg} / \mathrm{kg})$ was exceeded in two and three samples from groups I and III, respectively.

The highest levels of the macroelements analyzed in the wild boar livers were recorded in the case of $\mathrm{K}, \mathrm{Ca}$, and $\mathrm{Mg}$ (Table 3). The content of potassium in group II was statistically significantly different from that in groups I and III $(p \leq 0.01)$. The livers from group III were characterized by the highest $\mathrm{Mg}$ concentration. Significant differences $(p \leq 0.05)$ in the concentration of this element were also observed between groups I and II. No statistically significant differences were noted in the case of the Ca content, but there was a tendency towards lower levels of the element in the liver samples from group III. There was only a slight variation in the level of $\mathrm{N}$, and its mean content in the livers of the wild boars was $3610 \mathrm{mg} \cdot \mathrm{kg}^{-1}$. Statistically significant differences $(p \leq 0.01)$ were noted in the phosphorus concentration between group II and the other groups.

In the case of microelements (Table 4$)$, there were statistically significant differences $(p \leq 0.01)$ in the content of Fe between groups II and III. Substantially lower values of $\mathrm{Zn}$ and $\mathrm{Cu}$ were recorded in the livers from group I, compared with group II. The Ni content in all the groups was below the limit of quantification. The Mn content was statistically significantly higher $(p \leq 0.01)$ in group I in comparison with groups II and III.

The statistical analysis of the results (Tables 2-4) demonstrated that the animals' sex had a significant effect on the content of $\mathrm{Cd}, \mathrm{Ca}$, and Fe. Livers sampled from males were characterized by a significantly higher level of $\mathrm{Cd}$ and $\mathrm{Fe}$. In turn, livers taken from females exhibited a higher level of $\mathrm{Ca}$. There was no effect of the sex on the content of other minerals, although there was a tendency towards 
a higher concentration of $\mathrm{Zn}$ in the livers of males. The analyses revealed an interaction between the age and sex with respect to the content of potassium, copper, and manganese.

The calculation of EDI for the three adopted scenarios and the HQ and HI in children and adults are presented in Tables 5-7. The highest HQ values were observed for $\mathrm{Fe}, \mathrm{Cd}, \mathrm{Cu}$, and $\mathrm{Zn}$ in the consumed liver of groups I, II, and III. However, in all the scenarios, the HQ was found to be lower than 1. In the frequent consumption scenario, the hazard index (HI) values were higher than 1 for children. In the liver of wild boar, the highest $\mathrm{HI}$ values were recorded for $\mathrm{Fe}, \mathrm{Cd}, \mathrm{Cu}$, and $\mathrm{Zn}: 40 \%, 27 \%, 14 \%$, and $10 \%$, respectively. In the case of adults, all $\mathrm{HI}$ values were below 1 , both for the occasional and weekly consumption of the liver. 
Table 2. Concentration of trace elements in wild boar liver $\left(\mathrm{mg} \cdot \mathrm{kg}^{-1}\right.$ wet weight).

\begin{tabular}{|c|c|c|c|c|c|c|c|c|c|}
\hline Element & Parameter & Group I & Group II & Group III & Female & Male & Effects of Age & Effects of Sex & Interaction $\mathbf{A} \times \mathbf{S}$ \\
\hline \multirow[t]{3}{*}{$\mathrm{Pb}$} & Means \pm SE & $0.2636^{\mathrm{A}} \pm 0.116$ & $0.1630^{B} \pm 0.108$ & $0.2015 \pm 0.107$ & $0.195 \pm 0.103$ & $0.194 \pm 0.116$ & $* *$ & ns & ns \\
\hline & GM & 0.2420 & 0.1423 & 0.1764 & 0.1740 & 0.1641 & & & \\
\hline & Range & $0.122-0.520$ & $0.05-0.470$ & $0.07-0.38$ & $0.090-0.470$ & $0.048-0.520$ & & & \\
\hline \multirow[t]{3}{*}{$\mathrm{Cd}$} & Means \pm SE & $0.4405 \pm 0.226$ & $0.4227 \pm 0.178$ & $0.4485 \pm 0.284$ & $0.3802^{b} \pm 0.229$ & $0.4863^{a} \pm 0.200$ & ns & * & ns \\
\hline & GM & 0.3917 & 0.3561 & 0.3870 & 0.2942 & 0.4509 & & & \\
\hline & Range & $0.02-1.00$ & $0.17-0.23$ & $0.22-1.03$ & $0.020-1.00$ & $0.22-1.03$ & & & \\
\hline \multirow[t]{3}{*}{ As } & Means \pm SE & $0.0469 \pm 0.012$ & $0.0404 \pm 0.016$ & $0.0313 \pm 0.012$ & $0.0379 \pm 0.013$ & $0.0435 \pm 0.016$ & ns & ns & ns \\
\hline & GM & 0.0453 & 0.0375 & 0.0200 & 0.0356 & 0.0404 & & & \\
\hline & Range & $0.0315-0.0659$ & $0.0186-0.0791$ & $0.0120-0.0560$ & $0.0186-0.0692$ & $0.0120-0.0791$ & & & \\
\hline
\end{tabular}

A: Age; S: Sex; SE: Standard error; GM: Geometric mean; * means between the sexes in the same row with different letters are significantly different-a, b, $p<0.05$; ${ }^{* *}$ means between the groups in the same row with different letters are significantly different-A, B, $p<0.01$; ns: Not significant.

Table 3. Concentration of macroelements in wild boar liver (mg.kg ${ }^{-1}$ w.w.).

\begin{tabular}{|c|c|c|c|c|c|c|c|c|c|}
\hline Element & Parameter & Group I & Group II & Group III & Female & Male & Effects of Age & Effects of Sex & Interaction $\mathbf{A} \times \mathbf{S}$ \\
\hline \multirow[t]{3}{*}{-} & Means \pm SE & $2565^{\mathrm{A}} \pm 390.36$ & $2260^{B} \pm 249.09$ & $2709^{\mathrm{A}} \pm 429.77$ & $2432 \pm 296.73$ & $2374 \pm 410.81$ & $* *$ & ns & $* *$ \\
\hline & GM & 2535.59 & 2246.59 & 2680.03 & 2415.46 & 2340.85 & & & \\
\hline & Range & $1820-3110$ & $1821-2638$ & 2120-3410 & 1978-3110 & $1820-3410$ & & & \\
\hline \multirow[t]{3}{*}{$\mathrm{Ca}$} & Means \pm SE & $181.23 \pm 104.34$ & $249.76 \pm 127.39$ & $122.94 \pm 83.87$ & $232.96^{\mathrm{a}} \pm 117.42$ & $164.73^{b} \pm 114.34$ & ns & $*$ & ns \\
\hline & GM & 152.72 & 187.47 & 101.96 & 199.87 & 129.98 & & & \\
\hline & Range & $65.5-380$ & $32.8-458$ & $43.2-269$ & $43.2-458$ & $32.8-385$ & & & \\
\hline \multirow[t]{3}{*}{$\mathrm{Mg}$} & Means \pm SE & $191.63^{\mathrm{a}} \pm 17.07$ & $174.06^{\mathrm{b} B} \pm 22.12$ & $209.63^{\mathrm{A}} \pm 23.90$ & $183.25 \pm 14.58$ & $183.69 \pm 30.84$ & $* *$ & ns & ns \\
\hline & GM & 190.92 & 172.36 & 208.52 & 182.67 & 180.82 & & & \\
\hline & Range & $169-220$ & $102-200$ & $188-261$ & $150-208$ & $102-261$ & & & \\
\hline \multirow[t]{3}{*}{$\mathrm{N}$} & Means \pm SE & $3610 \pm 317$ & $3537 \pm 388$ & $3618 \pm 416$ & $3607 \pm 436$ & $3558 \pm 313$ & ns & ns & ns \\
\hline & GM & 3647 & 3516 & 3597 & 3581 & 3545 & & & \\
\hline & Range & $3163-4200$ & $2660-4230$ & $2970-4240$ & $2660-4231$ & $2960-4240$ & & & \\
\hline \multirow[t]{3}{*}{$\mathrm{P}$} & Means \pm SE & $1276^{\mathrm{A}} \pm 59$ & $1066^{\mathrm{B}} \pm 164$ & $1276^{\mathrm{A}} \pm 175$ & $1138 \pm 188$ & $1160 \pm 168$ & $* *$ & ns & ns \\
\hline & GM & 1274 & 1052 & 1260 & 1120 & 1147 & & & \\
\hline & Range & $1150-1350$ & $700-1350$ & $1000-1560$ & $750-1560$ & $701-1400$ & & & \\
\hline
\end{tabular}

SE: Standard error; GM: Geometric mean; * Means between the sexes in the same row with different letters are significantly different-a, $\mathrm{b} p<0.05 ; * *$ means in the same row with different letters are significantly different-A, B $p<0.01$; ns: Not significant. 
Table 4. Concentration of microelements in wild boar liver (mg.kg ${ }^{-1}$ w.w.).

\begin{tabular}{|c|c|c|c|c|c|c|c|c|c|}
\hline Element & Parameter & Group I & Group II & Group III & Female & Male & Effects of Age & Effect of Sex & Interaction $\mathrm{A} \times \mathrm{S}$ \\
\hline \multirow[t]{3}{*}{$\mathrm{Fe}$} & Means $\pm \mathrm{SE}$ & $408.51 \pm 135.69$ & $344.33^{B} \pm 98.27$ & $535.75^{\mathrm{A}} \pm 89.81$ & $331.35^{\mathrm{B}} \pm 88.97$ & $435.64^{\mathrm{A}} \pm 193.35$ & $* *$ & $* *$ & ns \\
\hline & GM & 390.28 & 331.73 & 476.56 & 321.46 & 404.70 & & & \\
\hline & Range & $259-696$ & $234-553$ & $286-1063$ & $234-553$ & $238-1063$ & & & \\
\hline \multirow[t]{3}{*}{$\mathrm{Cu}$} & Means \pm SE & $6.79^{b} \pm 0.99$ & $8.55^{\mathrm{a}} \pm 2.52$ & $8.82^{\mathrm{a}} \pm 2.94$ & $8.54 \pm 2.64$ & $7.75 \pm 2.12$ & * & ns & * \\
\hline & GM & 6.73 & 8.21 & 8.42 & 8.19 & 7.48 & & & \\
\hline & Range & $5.09-8.44$ & $4.37-14.90$ & $5.60-13.50$ & $5.87-14.90$ & $4.37-13.50$ & & & \\
\hline \multirow[t]{3}{*}{$\mathrm{Zn}$} & Means \pm SE & $50.24^{b} \pm 7.66$ & $61.10^{\mathrm{a}} \pm 14.98$ & $63.20^{\mathrm{a}} \pm 12.13$ & $54.73 \pm 14.39$ & $62.77 \pm 12.00$ & * & ns & ns \\
\hline & GM & 49.70 & 59.20 & 62.18 & 61.62 & 53.01 & & & \\
\hline & Range & $40.3-62.4$ & $31.6-89.00$ & $44.3-85.20$ & $44.3-83.34$ & $31.6-89.00$ & & & \\
\hline \multirow[t]{3}{*}{$\mathrm{Ni}$} & Means \pm SE & $<\mathrm{LOQ}=0.1$ & $<\mathrm{LOQ}=0.1$ & $<\mathrm{LOQ}=0.1$ & $<\mathrm{LOQ}=0.1$ & $<\mathrm{LOQ}=0.1$ & ns & ns & ns \\
\hline & GM & 0.099 & 0.095 & 0.091 & 0.097 & 0.093 & & & \\
\hline & Range & $<\mathrm{LOQ}=0.1$ & $<\mathrm{LOQ}=0.1$ & $<\mathrm{LOQ}=0.1$ & $0.08-0.10$ & $0.07-0.10$ & & & \\
\hline \multirow[t]{3}{*}{ Mn } & Means \pm SE & $3.300^{\mathrm{A}} \pm 0.505$ & $2.711^{\mathrm{B}} \pm 0.536$ & $2.487^{\mathrm{B}} \pm 0.432$ & $2.847 \pm 0.724$ & $2.831 \pm 0.441$ & $* *$ & ns & * \\
\hline & GM & 3.26 & 2.66 & 2.45 & 2.76 & 2.79 & & & \\
\hline & Range & $2.7-4.3$ & $2-4$ & $1.9-3.1$ & $1.9-4.3$ & $2-4.3$ & & & \\
\hline
\end{tabular}

SE: Standard error; GM: Geometric mean; LOQ: Limit of quan
with different letters are significantly different-A, $\mathrm{B} p<0.01$.

Table 5. Association of the estimated daily intake of elements, health risk (HQ), and hazard index (HI) with consumption of liver of the wild boar from group I.

\begin{tabular}{|c|c|c|c|c|c|c|c|c|c|c|c|c|}
\hline \multirow{3}{*}{ Element } & \multicolumn{6}{|c|}{ Estimated Daily Intake (EDI, mg/kg b.w.) } & \multicolumn{6}{|c|}{ Health Risk (HQ) for Consumers } \\
\hline & \multicolumn{2}{|c|}{$\begin{array}{c}\text { Frequent } \\
\text { Consumption } \\
\text { (90 times/year) }\end{array}$} & \multicolumn{2}{|c|}{$\begin{array}{l}\text { Periodic Consumption } \\
\text { (12 times/year) }\end{array}$} & \multicolumn{2}{|c|}{$\begin{array}{l}\text { Occasional Consumption } \\
\text { (two times/year) }\end{array}$} & \multicolumn{2}{|c|}{$\begin{array}{c}\text { Frequent } \\
\text { Consumption } \\
\text { (90 times/year) }\end{array}$} & \multicolumn{2}{|c|}{$\begin{array}{l}\text { Periodic Consumption } \\
\quad \text { (12 times/year) }\end{array}$} & \multicolumn{2}{|c|}{$\begin{array}{c}\text { Occasional } \\
\text { Consumption } \\
\text { (two times/year) }\end{array}$} \\
\hline & Children & Adult & Children & Adult & Children & Adult & Children & Adult & Children & Adult & Children & Adult \\
\hline $\mathrm{Fe}$ & 0.46526 & 0.19026 & 0.06203 & 0.02536 & 0.01033 & 0.00422 & 0.66466 & 0.27181 & 0.06203 & 0.03624 & 0.01477 & 0.00604 \\
\hline $\mathrm{Cu}$ & 0.00802 & 0.00328 & 0.00106 & 0.00043 & 0.00017 & $7.29 \times 10^{-5}$ & 0.20049 & 0.08198 & 0.02673 & 0.01093 & 0.00445 & 0.00182 \\
\hline $\mathrm{Zn}$ & 0.05924 & 0.02422 & 0.00789 & 0.00043 & 0.00131 & 0.00053 & 0.19474 & 0.08075 & 0.02633 & 0.01076 & 0.00438 & 0.00179 \\
\hline $\mathrm{Ni}$ & 0.00011 & 0.00004 & $1.58 \times 10^{-5}$ & $6.45 \times 10^{-6}$ & $2.63 \times 10^{-6}$ & $1.07 \times 10^{-6}$ & 0.00591 & 0.00241 & 0.00078 & 0.00032 & 0.00013 & 0.00005 \\
\hline $\mathrm{Mn}$ & 0.00388 & 0.00158 & 0.00051 & 0.00021 & $8.64 \times 10^{-5}$ & 0.00003 & 0.02776 & 0.01135 & 0.00370 & 0.00151 & 0.00061 & 0.00025 \\
\hline As & $5.4 \times 10^{-5}$ & 0.00002 & $7.2 \times 10^{-6}$ & 0.000002 & $2.20 \times 10^{-6}$ & $4.91 \times 10^{-7}$ & 0.00385 & 0.00157 & 0.00051 & 0.00021 & $8.57 \times 10^{-5}$ & 0.00003 \\
\hline $\mathrm{Pb}$ & 0.00028 & 0.00011 & $3.85 \times 10^{-5}$ & 0.00001 & $6.41 \times 10^{-6}$ & $2.62 \times 10^{-6}$ & 0.08242 & 0.03370 & 0.01099 & 0.00449 & 0.00183 & 0.00074 \\
\hline $\mathrm{Cd}$ & 0.00046 & 0.00019 & 0.000060 & 0.00002 & 0.00001 & $4.24 \times 10^{-6}$ & 0.46696 & 0.19095 & 0.06226 & 0.02546 & 0.01037 & 0.00424 \\
\hline $\mathrm{HI}$ & & & & & & & 1.64955 & 0.67457 & 0.21994 & 0.08994 & 0.03665 & 0.00869 \\
\hline
\end{tabular}


Table 6. Association of the estimated daily intake of elements, health risk (HQ), and hazard index (HI) with consumption of liver of the wild boar from group II.

\begin{tabular}{|c|c|c|c|c|c|c|c|c|c|c|c|c|}
\hline \multirow{3}{*}{ Element } & \multicolumn{6}{|c|}{ Estimated Daily Intake (EDI, mg/kg b.w.) } & \multicolumn{6}{|c|}{ Health Risk (HQ) for Consumers } \\
\hline & \multicolumn{2}{|c|}{$\begin{array}{c}\text { Frequent } \\
\text { Consumption } \\
\text { (90 times/year) }\end{array}$} & \multicolumn{2}{|c|}{$\begin{array}{l}\text { Periodic Consumption } \\
\quad \text { (12 times/year) }\end{array}$} & \multicolumn{2}{|c|}{$\begin{array}{l}\text { Occasional Consumption } \\
\text { (two times/year) }\end{array}$} & \multicolumn{2}{|c|}{$\begin{array}{c}\text { Frequent } \\
\text { Consumption } \\
\text { (90 times/year) }\end{array}$} & \multicolumn{2}{|c|}{$\begin{array}{l}\text { Periodic Consumption } \\
\quad \text { (12 times/year) }\end{array}$} & \multicolumn{2}{|c|}{$\begin{array}{l}\text { Occasional Consumption } \\
\text { (two times/year) }\end{array}$} \\
\hline & Children & Adult & Children & Adult & Children & Adult & Children & Adult & Children & Adult & Children & Adult \\
\hline $\mathrm{Fe}$ & 0.39545 & 0.16171 & 0.05272 & 0.02156 & 0.00878 & 0.00035 & 0.56493 & 0.00926 & 0.07532 & 0.03080 & 0.01255 & 0.00513 \\
\hline $\mathrm{Cu}$ & 0.00978 & 0.00400 & 0.00130 & 0.00053 & 0.00021 & $8.89 \times 10^{-5}$ & 0.24456 & 0.10001 & 0.03260 & 0.01333 & 0.00543 & 0.00222 \\
\hline $\mathrm{Zn}$ & 0.07057 & 0.02886 & 0.00941 & 0.00384 & 0.00156 & 0.00064 & 0.23521 & 0.09620 & 0.03136 & 0.01282 & 0.00522 & 0.00213 \\
\hline $\mathrm{Ni}$ & 0.00011 & $4.63 \times 10^{-5}$ & $1.51 \times 10^{-5}$ & $6.18 \times 10^{-6}$ & $2.52 \times 10^{-6}$ & $1.03 \times 10^{-6}$ & 0.00566 & 0.00231 & 0.00075 & 0.00030 & 0.00012 & $5.14 \times 10^{-5}$ \\
\hline $\mathrm{Mn}$ & 0.00317 & 0.00129 & 0.00042 & 0.00017 & $7.05 \times 10^{-5}$ & $2.88 \times 10^{-5}$ & 0.02265 & 0.00926 & 0.00302 & 0.00123 & 0.00050 & 0.00020 \\
\hline As & $4.47 \times 10^{-5}$ & $1.82 \times 10^{-5}$ & $5.96 \times 10^{-5}$ & $2.44 \times 10^{-5}$ & $9.93 \times 10^{-7}$ & $4.06 \times 10^{-7}$ & 0.00319 & 0.00130 & 0.00042 & 0.00017 & $7.10 \times 10^{-5}$ & $2.90 \times 10^{-5}$ \\
\hline $\mathrm{Pb}$ & 0.00017 & $6.94 \times 10^{-5}$ & $2.26 \times 10^{-5}$ & $9.25 \times 10^{-6}$ & $3.77 \times 10^{-6}$ & $1.54 \times 10^{-6}$ & 0.04846 & 0.01982 & 0.00646 & 0.00262 & 0.00107 & 0.00044 \\
\hline $\mathrm{Cd}$ & 0.00042 & 0.00017 & $5.66 \times 10^{-5}$ & $2.31 \times 10^{-5}$ & $9.43 \times 10^{-6}$ & $3.86 \times 10^{-6}$ & 0.42452 & 0.17360 & 0.05660 & 0.02314 & 0.00943 & 0.00385 \\
\hline $\mathrm{HI}$ & & & & & & & 1.54923 & 0.63354 & 0.20656 & 0.08447 & 0.03442 & 0.01407 \\
\hline
\end{tabular}

Table 7. Association of the estimated daily intake of elements, health risk (HQ), and hazard index (HI) with consumption of liver of the wild boar from group III.

\begin{tabular}{|c|c|c|c|c|c|c|c|c|c|c|c|c|}
\hline \multirow{3}{*}{ Element } & \multicolumn{6}{|c|}{ Estimated Daily Intake (EDI, mg/kg b.w.) } & \multicolumn{6}{|c|}{ Health Risk (HQ) for Consumers } \\
\hline & \multicolumn{2}{|c|}{$\begin{array}{c}\text { Frequent } \\
\text { Consumption } \\
\text { (90 times/year) }\end{array}$} & \multicolumn{2}{|c|}{$\begin{array}{l}\text { Periodic Consumption } \\
\quad \text { (12 times/year) }\end{array}$} & \multicolumn{2}{|c|}{$\begin{array}{l}\text { Occasional Consumption } \\
\text { (two times/year) }\end{array}$} & \multicolumn{2}{|c|}{$\begin{array}{c}\text { Frequent } \\
\text { Consumption } \\
\text { (90 times/year) }\end{array}$} & \multicolumn{2}{|c|}{$\begin{array}{l}\text { Periodic Consumption } \\
\quad \text { (12 times/year) }\end{array}$} & \multicolumn{2}{|c|}{$\begin{array}{l}\text { Occasional Consumption } \\
\text { (two times/year) }\end{array}$} \\
\hline & Children & Adult & Children & Adult & Children & Adult & Children & Adult & Children & Adult & Children & Adult \\
\hline $\mathrm{Fe}$ & 0.56693 & 0.23184 & 0.07559 & 0.03091 & 0.01259 & 0.00515 & 0.80990 & 0.33102 & 0.10798 & 0.04416 & 0.01799 & 0.00736 \\
\hline $\mathrm{Cu}$ & 0.01003 & 0.00410 & 0.00133 & 0.00054 & 0.00022 & $9.12 \times 10^{-5}$ & 0.25092 & 0.10261 & 0.03345 & 0.01368 & 0.00557 & 0.00228 \\
\hline $\mathrm{Zn}$ & 0.07412 & 0.03031 & 0.00988 & 0.00404 & 0.00164 & 0.00067 & 0.24707 & 0.10103 & 0.03294 & 0.01347 & 0.00549 & 0.00224 \\
\hline $\mathrm{Ni}$ & 0.00010 & $4.44 \times 10^{-5}$ & $1.45 \times 10^{-5}$ & $5.92 \times 10^{-6}$ & $2.41 \times 10^{-6}$ & $9.87 \times 10^{-7}$ & 0.00543 & 0.00222 & 0.00072 & 0.00029 & 0.00012 & $4.93 \times 10^{-5}$ \\
\hline Mn & 0.00291 & 0.00119 & 0.00038 & 0.00015 & $6.49 \times 10^{-5}$ & $2.65 \times 10^{-5}$ & 0.02086 & 0.00853 & 0.00278 & 0.00113 & 0.00046 & 0.00019 \\
\hline As & $2.38 \times 10^{-5}$ & $9.57 \times 10^{-6}$ & $3.18 \times 10^{-6}$ & $1.30 \times 10^{-6}$ & $5.30 \times 10^{-7}$ & $2.17 \times 10^{-7}$ & 0.00170 & 0.00069 & 0.00022 & $9.29 \times 10^{-5}$ & $3.78 \times 10^{-5}$ & $1.55 \times 10^{-5}$ \\
\hline $\mathrm{Pb}$ & 0.00021 & $8.60 \times 10^{-5}$ & $2.80 \times 10^{-5}$ & $1.15 \times 10^{-5}$ & $4.67 \times 10^{-6}$ & $1.91 \times 10^{-6}$ & 0.06008 & 0.02457 & 0.00801 & 0.00327 & 0.00133 & 0.00054 \\
\hline $\mathrm{Cd}$ & 0.000461 & 0.00018 & $6.15 \times 10^{-5}$ & $2.52 \times 10^{-5}$ & $1.03 \times 10^{-5}$ & $4.19 \times 10^{-6}$ & 0.46135 & 0.18866 & 0.06151 & 0.02515 & 0.01025 & 0.00419 \\
\hline $\mathrm{HI}$ & & & & & & & 1.85734 & 0.75954 & 0.24764 & 0.10127 & 0.04127 & 0.01687 \\
\hline
\end{tabular}




\section{Discussion}

A higher concentration of $\mathrm{Cd}$ was noted in the present investigations in the group of the youngest wild boars and over three year old animals. The concentration of this element in the former group of animals may be a result of higher intestinal absorption and the underdeveloped blood-brain barrier [30]. Halamić and Miko [31] found that the presence of cadmium in $83 \%$ of samples of kidney tissue at a concentration more than 10 times higher than that in the soil supports the tendency of cadmium accumulation in the body already in the first year of life. It has been proved that the younger the organism is, the greater its ability to absorb $\mathrm{Cd}$ is, and there is a positive correlation between cadmium concentrations and animals' age [12,13]. The cadmium concentrations in the present study are in agreement with those reported by Rudy [10] and Gasparik et al. [32], who analyzed the content of this element in wild boar livers. The content of the metal exceeded the highest allowable level $\left(0.5 \mathrm{mg} \cdot \mathrm{kg}^{-1}\right)$ in two samples from group I and three samples from group III. This may have been associated with the individual tendency to absorb and accumulate cadmium. As reported by Rudy [11], the maximum $\left(0.5 \mathrm{mg} \cdot \mathrm{kg}^{-1}\right)$ permissible level of cadmium in the liver was exceeded only in two samples in the group of over three year old animals. Any quantitative changes in the environment are reflected in animal tissues but, as suggested by Rudy [10], the sensitivity of these "living sensors" is highly variable, even within the same species. Our data on the $\mathrm{Cd}$ content in the wild boar livers differ from the results published by Chiari et al. [24], who reported a Cd concentration of $0.52-0.64 \mathrm{mg} \cdot \mathrm{kg}^{-1}$ in the livers of wild boars living in a mountainous environment in northern Italy. Slightly higher values were reported by Chiari et al. [24] in investigations on livers of wild boars from one of the districts in Italy and by Mandas [33], who analyzed the concentration of $\mathrm{Cd}$ in the livers of wild boars from Sardinia. As demonstrated by Szkoda et al. [1], particularly high concentrations of this metal (3.095 $\mathrm{mg} \cdot \mathrm{kg}^{-1}$ of fresh weight) were reported from Upper Silesia. A significantly higher Cd level was found in the males than in the females in the present study, which may be related to their diet. In comparison with females, wild boar males consume greater amounts of protein and are characterized by higher feed intake. Furthermore, invertebrates (i.e., snails) have been found to provide important links in transferring heavy metals from plant to carnivores [34].

A comparison of the present results with the current values specified by the EU recommendations, i.e., the allowable cadmium content in the liver of $0.5 \mathrm{mg} / \mathrm{kg}$, allows a conclusion that the values demonstrated in this research are lower than those defined in the regulations [22]. Since the amount of cadmium in the wild boar livers does not exceed the maximum allowable level, these parts can be recommended for human consumption, although there is a general recommendation for consumers that ingestion of offal from game animals should be avoided [12]. In our opinion, lead poses a considerable threat to human health only at a high concentration, even at infrequent consumption of game meat. Nevertheless, there is a need to control venison in order to protect consumers' health and undertake effective steps to eliminate this problem.

The average $\mathrm{Pb}$ content in this study was $0.21 \mathrm{mg} \cdot \mathrm{kg}^{-1}$; therefore, the level of this element was lower than the EU minimum risk for swine offal, i.e., $0.5 \mathrm{mg} \cdot \mathrm{kg}^{-1} \mathrm{ww}$. [22]. The mean contents detected in the liver were similar to those reported by Mandas [29] in wild boars aged 3-5 years from Sardinia, wild boars assessed by Rudy [10], and wild boars aged 1-5 years from central Poland analyzed by Długaszek and Kopczyński [35]. Pilarczyk et al. [29] detected an average $\mathrm{Pb}$ concentration of $0.702 \mathrm{mg} / \mathrm{g}$ in the liver of wild boars from western Ukraine, which was three times as high as that found in this study. A higher $\mathrm{Pb}$ concentration was recorded by Amici et al. [23] in wild boars living in six areas of Viterbo Province and by Živkov Balos et al. [5], who analyzed livers of wild boars originating from 16 regions of Serbia. In the case of age, Chiari et al. [24] did not find a difference between wild boars below and above 1 year of age, as in the present study. In wild boar habitats located near an industrial complex, Martelli [36] detected a substantial level of lead in the liver, kidneys, and muscles. Similar results were reported by Szkoda et al. [1], who analyzed livers of wild boars originating from Bogatynia and Upper Silesia, and by Durkalec et al. [37], who examined livers of wild boars living in an area regarded as the most toxic metal contaminated part of the Upper Silesia region. In their analyses 
of the content of toxic elements in wild boars from a mining area of the Ciudad Real Province in Spain, Taggart et al. [38] found an average Pb level in the liver of $1.675 \mathrm{mg} \cdot \mathrm{kg}^{-1} \mathrm{~d}$.w. In turn, the highest concentration of $\mathrm{Pb}$, i.e., on average $2.28 \mathrm{mg} \cdot \mathrm{kg}^{-1}$, was observed by Kryński et al. [39] in the livers of wild boars from south-western Poland.

The $\mathrm{Pb}$ concentrations detected in animal tissues indicate that this element is present in various components of the environment and is capable of bioaccumulation in the trophic chain. In 2010, on the request of the European Commission, the Scientific Panel on Contaminants in the Food Chain of the European Food Safety Authority [40] analyzed the results of toxicological studies conducted in recent years and new data on food contamination with lead. They concluded that the current value of provisional tolerable weekly intake (PTWI) of lead specified at $25 \mu \mathrm{g} / \mathrm{kg}$ b.w., i.e., $3.57 \mu \mathrm{g} \mathrm{Pb} / \mathrm{kg}$ b.w./day, should be replaced by lower doses determining the BMDL (Benchmark Dose Lower Confidence Limit). The lowest doses are associated with induction of a specific effect on the human organism. Permissible values of the index were set at the following levels: $\mathrm{BMDL}_{01}$ for children (neurotoxic effect) $0.50 \mu \mathrm{g} \cdot \mathrm{kg}^{-1}$ b.w./day as well as BMDL $100.63 \mu \mathrm{g} \cdot \mathrm{kg}^{-1} \mathrm{~b} . \mathrm{w} . /$ day (nephrotoxic effect) and BMDL $\mathrm{B}_{01}$ $1.50 \mu \mathrm{g} \cdot \mathrm{kg}^{-1} \mathrm{~b} . \mathrm{w}$./day (cardiovascular disorders) for adults [40].

In terms of the As content, a similar concentration was detected by Taggart et al. [38] and Kucharczak and Motyl [25], who assessed the content of this element in the livers of wild boars living in industrial areas, agricultural regions, and urban agglomerations. Referring to the levels of this element recorded in the literature, it was found that the wild boars examined in the present study had much lower levels of As than those in Ukraine [29]. In an analysis of the content of trace elements in the wild boar livers, Rudy [10] reported contents of arsenic lower than $0.001 \mathrm{mg} \cdot \mathrm{kg}^{-1}$. The European Union regulations do not specify the maximum level of As in meat and liver; therefore, the interpretation of our result in this aspect is somewhat difficult.

Potassium is one of the macronutrients. It is an important element in water-electrolyte metabolism and acid-base homeostasis in the organism. The variability of the $\mathrm{K}$ concentration in the present study was in the range of $1820-3410 \mathrm{mg} \cdot \mathrm{kg}^{-1}$. Similar levels of this element were reported by Sales and Kotrba [41] in meat from wild boars from Slovakia. The results of the Ca concentration coincide with those observed by Długaszek and Kopczyński [35]. Ca plays an important role in the process of organism growth. The mean Mg content in the livers of the analyzed wild boar groups was similar to that recorded by Długaszek and Kopczyński [35]. Substantially higher values of the Mg concentration in the range of $810-1060 \mathrm{mg} \cdot \mathrm{kg}^{-1}$ were observed by Roślewska et al. [42]. These differences may be associated with the dissimilarities in the animals' habitats, differences in the feed base, and the different methodology of determination of the component.

The investigations reported by Babicz et al. [19] show that edible slaughter by products are the main store of Fe. Importantly, Fe contained in offal is heme iron, the absorption of which is several-fold higher than the absorption of non-heme iron contained in other raw materials and food products. The high levels of these elements are associated with their high oxidative metabolism in the cells [43]. The wild boar liver is a rich source of iron; its content in the present study was, on average, $429.53 \mathrm{mg} \cdot \mathrm{kg}^{-1}$ at $\mathrm{SD}=181.18$. As shown by Pilarczyk et al. [29], the Fe content in wild boar liver was highly variable and ranged from 82.40 to $301.00 \mathrm{mg} \cdot \mathrm{kg}^{-1}$. A substantially lower variability in the concentration of this component was reported by Skobrák et al. [44].

The livers sampled from the males in the present study exhibited a higher level of Fe and a lower concentration of $\mathrm{Ca}$, compared with gilts. It can be assumed that the higher Fe levels are associated with the higher activity and increased oxidative metabolism in males [19]. The mean zinc content in the wild boar livers analyzed in this study was similar to the value reported by Roślewska et al. [42] and higher than that recorded by Skobrák et al. [44]. A high level of zinc in the dose is not dangerous to the organism, as this element is easily excreted in feces [45]. With regard to the Cu content, similar results were reported by Roślewska et al. [42], who analyzed wild boar meat (from males and females). In investigations of the $\mathrm{Cu}$ concentration in wild boar meat, Długaszek and Kopczyński [18] found lower values and a high variability of this component (from 0.15 to $1.79 \mathrm{mg} \cdot \mathrm{kg}^{-1}$ ). The content of 
Mn in the present study was the highest in the livers of the youngest wild boars, which is probably associated with individual tendencies to absorb and accumulate metals. As demonstrated by Długaszek and Kopczyński [18], the content of $\mathrm{Mn}$ in wild boar meat varied widely in the range from 0.08 to $1.39 \mathrm{mg} \cdot \mathrm{kg}^{-1}$. The differences in the content of some minerals $(\mathrm{K}, \mathrm{Mg}, \mathrm{P}, \mathrm{Cd}, \mathrm{Zn}, \mathrm{Cu}$, and $\mathrm{Mn})$ in relation to animals' age and sex may be related to several factors. As reported by Ping et al. [46], the bio-concentration of metals depends on the differences in metal uptake, storage, and regulatory mechanisms within species.

In this study, the values of $\mathrm{HQ}$ of individual metals in the liver were below 1 , which indicates that the frequent intake of these metals is unlikely to cause adverse health effects in adult consumers. However, a frequent intake of the liver studied may exert adverse health effects on children due to the content of $\mathrm{Fe}, \mathrm{Cd}, \mathrm{Cu}$, and $\mathrm{Zn}$. The zinc concentration was within the allowable daily doses of this element for an adult human (10-40 mg/day, after World Health Organization). As specified by the Food and Agriculture Organization of the United Nations/World Health Organization recommendations, the tolerable consumption of cadmium by an adult human is approx. $0.4-0.5 \mathrm{mg} / \mathrm{week}$, and the allowable dose is 60-70 $\mu \mathrm{g}$ per day [6,47]. Dietary levels of protein, zinc, copper, calcium, and iron compounds exert a considerable impact on the uptake of cadmium from the gastrointestinal tract. Low levels of these elements in food increases absorption of cadmium from the gastrointestinal tract and accumulation in the organism. Increased amounts of zinc in food reduce the intensity of cadmium absorption from the gastrointestinal tract. Therefore, the likelihood of appearance of symptoms of cadmium intoxication immediately after consuming wild boar liver is small, even if the concentration of this metal exceeds the allowable levels, as the digestibility of the element is approx. $10 \%$ [47]. The Cd level in the liver of wild boars from groups I and III only in two and three samples, respectively, slightly exceeded the maximum permissible concentration of this element in foodstuffs. However, this metal has the ability to bioaccumulate, e.g., in the liver and kidneys $[10,14]$. Increased cadmium content in food has a remarkably negative impact on the health of children, as it reduces the immune resistance of young organisms. Moreover, cadmium is one of the most serious factors increasing the risk of cancer diseases in children [47]. The offal is an excellent source of highly available $\mathrm{Na}, \mathrm{Ca}$, and trace elements (mainly $\mathrm{Fe}, \mathrm{Mn}$, and $\mathrm{Cu}$ ) [20]. Bioavailability of iron is greatest when it is in the heme form, and meat is the primary source of this form. As reported by Babicz et al. [19], meat-derived iron is characterized by approximately $20-30 \%$ availability. It was found that the HI values associated with the consumption of liver of wild boar were 2.5 fold higher for children than for adults. Similar values were also reported by Pilarczyk et al. [29]. Kicińska et al. [15] reported that in scenarios with daily and weekly consumption of animal liver, the final HI calculated for children was approx. 3.5 times higher than for adults. Kicińska et al. [15] reported a potential risk to health associated with the consumption of liver from game animals $(\mathrm{HI}>1)$. In contrast, Lazarus et al. [48] indicated that consumption of game meat and liver in Croatia did not pose a health risk to consumers, regardless of the exposure scenario. Nevertheless, the authors suggested that children should avoid eating game liver, because a high percentage of samples were found to exceed the permitted limits for $\mathrm{Cd}$ and $\mathrm{Pb}$.

\section{Conclusions}

Liver from wild boar can be an important source of minerals in the diet of hunting communities. The age was found to exert an effect on the concentration of $\mathrm{Pb}, \mathrm{K}, \mathrm{Mg}, \mathrm{P}, \mathrm{Fe}, \mathrm{Mn}, \mathrm{Cu}$, and $\mathrm{Zn}$. The Fe, $\mathrm{Cu}$, and $\mathrm{Zn}$ contents increased with age, whereas the Mn content decreased significantly. The livers from young wild boars contained the highest amounts of $\mathrm{Pb}$ and $\mathrm{P}$. In turn, the livers of animals from group III accumulated the highest levels of $\mathrm{K}, \mathrm{Fe}, \mathrm{Mg}, \mathrm{Zn}$, and $\mathrm{Cu}$. The investigations have confirmed increasing accumulation of Fe in the wild boar livers with age. The sex significantly determined the content of Fe, $\mathrm{Ca}$, and $\mathrm{Cd}$. The liver of the female boars contained less Fe and Cd but more $\mathrm{Ca}$. The higher content of Fe in the livers from the male than female animals may be associated with the higher muscle weight and hemoglobin content in males. In the group of the analyzed toxic elements $(\mathrm{Pb}, \mathrm{Cd}, \mathrm{As})$, the highest and lowest levels were determined for $\mathrm{Cd}$ and $\mathrm{As}$, respectively. The concentration of $\mathrm{Pb}$ and $\mathrm{As}$ in 
the analyzed livers does not raise concern. These values are generally lower than those recorded in other European countries. The liver Cd concentration in $12.5 \%$ (up to one year old wild boars) and $11.5 \%$ (over three year old animals) of the liver samples were above the European Union Maximum Residue Levels (MRL) established for offal destined for human consumption. The concentration of this element in the young wild boars may be a result of the higher intake thereof with sow's milk. In the livers of older wild boars, it may be associated with migration of the animals into non-agricultural areas characterized by a higher cadmium concentration. However, the mean $\mathrm{Cd}$ levels were in the range of physiological concentrations and did not exceed the permissible temporal limits specified for the liver of farm animals. However, regular control of the content of this element in game animal tissues is extremely important and advisable for assessment of the level of consumer exposure to this metal. Additionally, further research is required to identify the source of pollution in order to protect the health of both animals and humans. This research shows that the younger the organism is, the greater its ability to absorb $\mathrm{Pb}$ and $\mathrm{Cd}$ is. The average $\mathrm{Pb}$ content in this study was lower than the EU minimum risk for swine offal. This confirms the satisfactory status of the agricultural environment in the area of wild boar foraging (crop fields, forests). Children should avoid a frequent intake of liver from wild boar. Based on the calculated HI values, it seems recommendable that consumption of the liver by children should be limited to one such a meal monthly. Adults can consume wild boar liver even twice a week.

Author Contributions: Conceptualization, A.K.; funding acquisition, J.K., S.C.; investigation, S.C.; writing—original draft preparation, A.K.; writing—review and editing, J.K.,A.K. and S.C.; supervision, A.K.; validation, M.R. All authors have read and agreed to the published version of the manuscript

Funding: This research received no external funding.

Conflicts of Interest: The authors declare no conflict of interest.

\section{References}

1. Szkoda, J.; Durkalec, M.; Kołacz, R.; Opaliński, S.; Żmudzki, J. Content of cadmium, lead and mercury in the tissues of game animals. Med. Weter. 2012, 68, 689-692.

2. Chrastný, V.; Vaněk, A.; Teper, L.; Cabala, J.; Procházka, J.; Pechar, L.; Drahota, P.; Penížek, V.; Komárek, M.; Novák, M. Geochemical position of $\mathrm{Pb}, \mathrm{Zn}$ and $\mathrm{Cd}$ in soils near the Olkusz mine/smelter, South Poland: Effects of land use, type of contamination and distance from pollution source. Environ. Monit. Assess. 2012, 184, 2517-2536. [CrossRef] [PubMed]

3. O'Neill, A.; Phillips, D.H.; Bowen, J.; Sen, G.B. Contaminants in surface water and sediments near the Tynagh silver mine site, county Galway, Ireland. Sci. Total Environ. 2015, 512, 261-272. [CrossRef] [PubMed]

4. Srebočan, E.; Janicki, Z.; Crnić, A.P.; Tomljanović, K.; Sebečić, M.; Konjević, D. Cadmium, lead and mercury concentrations in selected red deer (Cervus elaphus L.) tissues from north-eastern Croatia. J. Environ. Sci. Health A Tox. Hazard Subst. Environ. Eng. 2012, 47, 2101-2108. [CrossRef] [PubMed]

5. Živkov-Balos, M.; Mihaljev, Ž.; Ljubojević, D.; Apić, J. Lead and Cadmium in Wild Boar from Different Grounds in Serbia. Available online: https://niv.ns.ac.rs/StariSajt/tr31084/fajlovi/15/36.2015.pdf (accessed on 7 August 2019).

6. Maciołek, H.; Zielińska, A.; Domarecki, T. The geobiological-chemical effect of cadmium and lead on the natural environment. J. Ecol. Health 2013, 17, 63-71.

7. Douay, F.; Pruvot, C.; Waterlot, C.; Fritsch, C.; Fourrier, H.; Loriette, A.; Bidar, G.; Grand, C.; De Vaufleury, A.; Scheifler, R. Contamination of woody habitat soils around a former lead smelter in the North of France. Sci. Total Environ. 2009, 407, 5564-5577. [CrossRef]

8. Šajn, R.; Aliu, M.; Stafilov, T.; Alijagić, J. Heavy metal contamination of topsoil around a lead and zinc smelter in Kosovska Mitrovica/Mitrovicë Kosovo/Kosovë. J. Geochem. Explor. 2013, 134, 1-16. [CrossRef]

9. Stafilov, T.; Šajn, R.; Pancevski, Z.; Boev, B.; Frontasyeva, M.V.; Strelkova, L.P. Heavy metal contamination of topsoils around a lead and zinc smelter in the Republic of Macedonia. J. Hazard. Mater. 2010, 175, 896-914. [CrossRef] 
10. Rudy, M. Contents of Environmental Contaminations in Tissues Depending on the Age of Animals and Chemical Composition of Meat. Ph.D. Thesis, Wyd. Uniwersytetu Rzeszowskiego, Rzeszów, Poland, 2010. (In Polish, in English abstract)

11. Yarsan, E.; Yipel, M.; Dikmen, B.; Altıntaş, L.; Ekici, H.; Köksal, A. Concentrations of essential and non-essential toxictrace elements in wild boar (Sus scrofa L., 1758) tissues from southern Turkey. Bull. Environ. Contam. Toxicol. 2014, 92, 10-14. [CrossRef]

12. Crnić, A.P.; Šuran, J.; Madunić, H.C.; Božić, F. Cadmium concentrations in the tissues of young wild boars (Sus scrofa L.) from Moslavina and Slavonia in lowland Croatia. Veterinarski Arhiv. 2015, 85, 323-334.

13. Srebočan, E.; Crnič, A.P.; Ekert-Kabalin, A.M.; Lazarus, M.; Jurasovič, J.; Tomljanovič, K.; Andreič, D.; Perović, I.S.; Čoz-Rakovac, R. Cadmium, lead, and mercury concentrations in tissues of roe deer (Capreolus capreolus L.) and wild boar (Sus scrofa L.) from lowland Croatia. Czechoslov. J. Food Sci. 2011, 29, 624-633. [CrossRef]

14. Bilandzić, N.; Sedak, M.; Vratarić, D.; Perić, T.; Simić, B. Lead and cadmium in red deer and wild boar from different hunting grounds in Croatia. Sci. Total Environ. 2009, 407, 4243-4247. [CrossRef] [PubMed]

15. Kicińska, A.; Glichowska, P.; Mamak, M. Micro- and macroelement contents in the liver of farm and wild animals and the health risks involved in liver consumption. Environ. Monit. Assess. 2019, 6, 132. [CrossRef] [PubMed]

16. Rani, A.; Kumar, A.; Lal, A.; Pant, M. Cellular mechanisms of cadmium-induced toxicity: A review. Int. J. Environ. Health B 2014, 24, 378-399. [CrossRef]

17. Šuran, J.; Prišć, M.; Rašić, D.; Srebočan, E.; Crnić, A.P. Malondialdehyde and heavy metal concentrations in tissues of wild boar (Sus scrofa L.) from central Croatia. J. Environ. Sci. Health B 2013, 48, 147-152. [CrossRef]

18. Długaszek, M.; Kopczyński, K. Elemental Composition of Muscle Tissue of Wild Animals from Central Region of Poland. Int. J. Environ. Res. 2013, 7, 973-978. [CrossRef]

19. Babicz, M.; Kasprzyk, A.; Kropiwiec-Domańska, K. Influence of the sex and type of tissue on the basic chemical composition and the content of minerals in the sirloin and offal of fattener pigs. Can. J. Anim. Sci. 2018, 99, 343-348. [CrossRef]

20. Pereira, P.M.D.C.C.; Vicente, A.F.D.R.B. Meat nutritional composition and nutritive role in the human diet. Meat Sci. 2013, 93, 586-592. [CrossRef] [PubMed]

21. Ustymowicz-Farbiszewska, J.; Fiłon, J.; Górski, J.; Karczewski, J.; Święcka, J. Comparative analysis of the trace element content in daily food rations of postsecondary school students in Bialystok and Warsaw. Probl. Hig. Epidemiol. 2014, 95, 107-114.

22. European Commission, EC 2008. Commission Regulation No 629/2008 of 2 July 2008 setting maximum levels for certain contaminants in foodstuffs. Off. J. Eur. Union L 2008, 173, 6-9.

23. Amici, A.; Danieli, P.P.; Russo, C.; Primi, R.; Ronchi, B. Concentrations of some toxic and trace elements in wild boar (Sus scrofa) organs and tissues in different areas of the province of Viterbo (Central Italy). Ital. J. Anim. Sci. 2012, 11, 354-362. [CrossRef]

24. Chiari, M.; Cortinovis, C.; Bertoletti, M.; Alborali, L.; Zanoni, M.; Ferretti, E.; Caloni, F. Lead, cadmium and organochlorine pesticide residues in hunted red deer and wild boar from northern Italy. Food Addit. Contam. Part A 2015, 49, 1-8. [CrossRef] [PubMed]

25. Kucharczak, E.; Moryl, A. Influence of environment on content of arsenic and aluminium in hunting animals parenchymal organs. Ochrona Środowiska i Zasobów Naturalnych 2012, 53, 89-96.

26. Ihiedioha, J.N.; Okoye, C.O.B.; Onyechi, U.A. Health risk assessment of zinc, chromium and nickel from cow meat consumption in an urban Nigerian population. Int. J. Occ. Environ. Health 2014, 20, 281-288. [CrossRef] [PubMed]

27. Polish Standard, PN-A-04018. Agricultural Food Products-Determination of Nitrogen by Kjeldahl; Polish Committee for Standardization: Warsaw, Poland, 1975; pp. 1-3. (In Polish)

28. Fiske, C.; Subbarow, Y. The colorimetric determination of phosphorus. J. Biol. Chem. 1925, 66, 375-400.

29. Pilarczyk, B.; Tomza-Marciniak, A.; Pilarczyk, R.; Udała, J.; Kruzhel, B.; Ligocki, M. Content of essential and non-essential elements in wild animals from western Ukraine and the health risks associated with meat and liver consumption. Chemosphere 2020, 244, 1-10. [CrossRef]

30. Krzywy, I.; Krzywy, E.; Peregud-Pogorzelski, J.; Łuksza, K.; Brodkiewicz, A. Cadmium-Is there something to fear? Annales Academiae Medicae Stetinensis. Rocz. AM w Szczecinie 2011, 57, 49-63.

31. Halamić, J.; Miko, S. Geochemical Atlas of the Republic of Croatia; Croatian Geological Survey: Zagreb, Croatia, 2009. 
32. Gasparik, J.; Dobias, M.; Capcarova, M.; Smehyl, P.; Slamecka, J.; Bujko, J. Concentration of cadmium, mercury, zinc, copper and cobalt in the tissues of wild boar (Sus scrofa) hunted in the western Slovakia. J. Environ. Sci. Health A 2012, 47, 1212-1216. [CrossRef]

33. Mandas, L. Problemi sanitari della fauna selvatica nelle oasi di protezione faunistica. In Proceedings of the Regional Congress on Ambiente e Sviluppo Sostenibile: La Nuova Provincia del Medio Campidano-Tutela e valoRizzazione Della Fauna Locale, Montevecchio (CA), Italy, 28 August 2005; pp. 3-11.

34. Gasparik, J.; Massányi, P.; Slamecka, J.; Fabis, M.; Jurcik, R. Concentration of selected metals in liver, kidney, and muscle of the red deer (Cervus elaphus). J. Environ. Sci. Health Part A. 2004, 39, 2105-2111. [CrossRef]

35. Długaszek, M.; Kopczyński, K. Comparative analysis of liver mineral status of wildlife. Probl. Hig. Epidemiol. 2011, 92, 859-863.

36. Martelli, P. Controllo Ispettivo Qualitativo di Carni di Cinghiale Regolarmente Macellati Nella Provincia di Siena. Master's Thesis, Università di Pisa, Pisa, Italy, 2005.

37. Durkalec, M.; Szkoda, J.; Kolacz, R.; Opalinski, S.; Nawrocka, A.; Żmudzki, J. Bioaccumulation of lead, cadmium and mercury in roe deer and wild boars from areas with different levels of toxic metal pollution. Int. J. Environ. Res. 2015, 9, 205-212. [CrossRef]

38. Taggart, M.A.; Reglero, M.M.; Camarero, P.R.; Mateo, R. Should legislation regarding maximum $\mathrm{Pb}$ and Cd levels in human food also cover large game meat? Environ. Int. 2011, 37, 18-25. [CrossRef] [PubMed]

39. Kryński, A.; Rokicki, E.; Wrzesień, R. Contamination of organs and tissues of roe deer and wild boars with heavy metals. X Kongres PTNW Wroctaw 1996, 1, 500.

40. EFSA Panel on Contaminants in the Food Chain (CONTAM). Scientific Opinion on Lead in Food. EFSA J. 2010, 8, 1570. [CrossRef]

41. Sales, J.; Kotrba, R. Meat from wild boar (Sus scrofa L.): A review. Meat Sci. 2013, 94, 187-201. [CrossRef]

42. Roślewska, A.; Stanek, M.; Janicki, B.; Cygan-Szczegielniak, D.; Stasiak, K.; Buzała, M. Effect of sex on the content of elements in meat from wild boars (Sus scrofa L.) originating from the Province of Podkarpacie (south-eastern Poland). J. Elementol. 2016, 21, 823-832. [CrossRef]

43. Kasprzyk, A.; Stasiak, A.; Babicz, M. Meat quality and ultrastructure of muscle tissue from fatteners of Wild Boar, Pulawska and its crossbreed Pulawska x (Hamshire x Wild Boar). Arch. Tierz. 2010, 53, 184-193. [CrossRef]

44. Skobrák, E.B.; Bodnár, K.; Jónás, E.M.; Gundel, J.; Jávor, A. The comparison analysis of the main chemical composition parameters of wild boar meat and pork. Lucrări Ştiinţifice, ser. Zootehnie si Biotehnol. 2011, $44,105-112$.

45. Węlarzy, K. Heavy metals-A source of contamination and environmental impact. Wiadomości Zoot. 2007, 3, 31-38.

46. Ping, Z.; Huiling, Z.; Wensheng, S. Biotransfer of heavy metals along a soil-plant-insect-chicken food chain: Field study. J. Environ. Sci. 2009, 21, 849-853.

47. Łuszczek-Trojnar, E.; Błoniarz, P.; Winiarski, B.; Drag-Kozak, E.; Popek, W. Comparison of cadmium, zinc, manganese and nickel concentrations in fillets of selected species of food fish. Rocz. Nauk. PTZ 2014, 11, 75-84.

48. Lazarus, M.; Crnic, A.P.; Bilandzic, N.; Kusak, J.; Reljic, S. Cadmium, lead, and mercury exposure assessment among Croatian consumers of freeliving game. Arh. Hig. Rada Toksikol. 2014, 65, 281-292. [CrossRef] [PubMed]

(C) 2020 by the authors. Licensee MDPI, Basel, Switzerland. This article is an open access article distributed under the terms and conditions of the Creative Commons Attribution (CC BY) license (http://creativecommons.org/licenses/by/4.0/). 